\title{
PENGUKURAN BEBAN KERJA DENGAN METODE FULL TIME EQUIVALENT DAN PENENTUAN JUMLAH TENAGA KERJA EFEKTIF MENGGUNAKAN WORKLOAD ANALYSIS
}

\author{
Bakhtiar $^{1}$, Syarifuddin ${ }^{1}$, Merlie Prasetyowati Putri ${ }^{1}$ \\ Jurusan Teknik Industri, Fakultas Teknik \\ Universitas Malikussaleh, Lhokseumawe, Aceh Indonesia \\ Jl. Kampus Unimal Bukit Indah, Blang Pulo, Muara Satu Aceh Utara \\ E-mail: bakhtiar@unimal.ac.id
}

\begin{abstract}
Abstrak- Toko Daffa merupakan salah satu wholesaler barang umum dapat diartikan sebagai pelaku usah ayang menjual barang dalam jumlah besar,dimana didistribusikan kepengecer, pengguna bisnis industri, komersial, institusi atau kepada penggrosiran di daerah kabupaten Batubara. Diketahui banyaknya karyawan tidak menjamin kecepatan pelayannya, Toko Daffa belum melakukan pengukuran beban kerja di setiap stasiun kerja sehingga menyebabkan ketidaksesuaian beban kerja sehingga membuat kinerja karyawan tidak efektif dan menimbulkan antrian di Toko Daffa. Tujuan dilakukan penelitian ini yaitu untuk mengetahui beban kerja yang diterima karyawan menggunakan metode Full Time Equivalent (FTE) dan jumlah tenaga kerja yang optimal menggunakan metode Workload Analysis. Berdasarkan hasil penelitian menggunakan metode FTE diketahui ada ketidakseimbangan beban kerja, pada divisi pencetak struk underload, divisi pengambil barang overload dan divisi kasir underload maka perlu perbaikan dengan menggabungkan elemen pekerjaan kasir dengan pencetak struk dan dilakukan penambahan tenaga kerja pada divisi pengambil orderan sebanyak 3 orang. Berdasarkan metode Workload Analysis didapatkan tidak perlu penambahan tenaga kerja pada divisi pencetak struk dan kasir, namun perlu penambahan tenaga kerja pada divisi pengambil barang sebanyak 3 orang.
\end{abstract}

Kata Kunci : Beban Kerja, Full Time Equivalent, Workload Analysis

\section{PENDAHULUAN}

$\mathrm{S}$ aat ini Toko Daffa menjadi salah satu wholesaler barang umum dapat diartikan sebagai pelaku usaha yang menjual barang dalam jumlah besar, dimana didistribusikan kepengecer, pengguna bisnis industri, komersial,institusi atau kepada pengrosiran lainnya.

Banyaknya karyawan tidak menjamin kecepatan pelayannya,dimana dibagian pengambil orderan mempunyai karyawan berjumlah 3 orang dibagian pencetakan struk belanjaan karyawan yang bertugas sejumlah 1 orang, kasir yang berjumlah 1 orang, supir yang berjumlah 3 orang, administrasi gudang berjumlah 1 orang dan administrasi took berjumlah 1 orang.
Karena kurangnya kecepatan pelayanan menyebabkan adanya antrian, maka dapat di ketahui bahwa dalam perencanaan jumlah tenaga kerja harus disesuaikan dengan beban kerja yang ada agar tidak mengakibatkan kerugian bagi perusahaan.Toko Daffa belum menerapkan pengukuran beban kerja pada stasiun kerja sehingga menyebabkan ketidak sesuaian penempatan jumlah pekerja sehingga membuat kinerja karyawan tidak efektif dan menimbulkan antrian di Toko Daffa. Hal penting yang menjadi perencanaan tenaga kerja itu dapat memungkinkan tenaga kerja dimanfaatkan secara lebih baik.

Berdasarkan masalah tersebut membahas tentang pengoptimalan kinerja karyawan maka dari itu perlunya adanya pengukuran beban kerja sebagai dasar perhitungan kebutuhan tenaga kerja yang optimal dengan menggunakan metode Full Time Equivalent (FTE) dimana metode ini menyelesaikan masalah dengan cara waktu pengukuran pekerjaan dibandingkan dengan waktu kerja efektif yang menghasilkan indeks FTE yang digunakan untuk menentukan beban kerja yang diterima, kemudian dianalisis kembali menggunakan metode Work Load Analysis untuk menentukan jumlah tenaga kerja yang optimal pada Toko Daffa.

Berdasarkan latar belakang masalah, maka dapat dirumuskan masalah, yaitu Bagaimana beban kerja yang diterima karyawan berdasarkan metode Full Time Equivalent dan berapa jumlah tenaga kerja optimal. Dengan mengambil tujuan dari penelitian ini adalah untuk mengetahui bagaimana beban kerja yang diterima operator dan mengetahu iberapa jumlah tenagakerja optimal.

Agar hasil yang diperoleh tidak menyimpang dari tujuan yang diinginkan, maka penelitian diberi batasan sebagaiberikut:

1. Penelitian dilakukan diToko Daffa

2. Data yang digunakan dalam penelitian ini adalah jumlah tenaga kerja, jumlah hari kerja dalam satu tahun dan satubulan.

3. Pengambilan waktu dalam penyelesaian pekerjaan pada bagianp pengambilan barang digunakan waktu pelayanan 6 produk.

\section{Pengertian Ergonomi}

Menurut Tarwa kadkk, (2004) bahwa,ergonomic adalah ilmu dan penerapan teknologi untuk menyerasikan atau men- 
seimbangkan antara segala fasilitas yang digunakan baik dalam beraktivita sistirahat dengan kemampuan dan keterbatasan manusia fisik maupun mental sehingga kualitas hidup secara keseluruhan menjadi baik.

\section{Sumber Daya Manusia}

Sumber daya manusia merupakan salah satu faktor penting dalam pembangunan. Secara makro,faktor-faktor masukkan pembangunan, seperti sumberdaya alam,material,dan financial tidak akan member manfaat secara optimal untuk perbaikan kesejahteraan rakyat tanpa didukung oleh ketersediaan faktor SDM yang memadai, baik secara kualitas maupun kuantitas.

\section{Full Time Equivalent (FTE)}

Metode Full Time Equivalent merupakan salah satu metode untuk melakukan pengukuran beban kerja yang berdasar pada waktu kerja dengan cara pengukuran lama waktu dalam menyelesaikan satu tugas yang diberikan, kemudian waktu tersebut akan dikonversikan ke dalam bentuk nilai indeks FTE. Indeks nilai FTE dikategorikan menjadi 3 bagian yaitu :

1. Underload (beban kerja masih kurang)=bila nilai indeks FTE antara 0-0.99

2. Normal (beban kerja sudah sesuai) $=$ nilai indeks FTE antara 1-1,28

3. Overload (beban kerja terlalu banyak)=nilai indeks FTE lebih besa rdari 1,28

\section{Langkah-langkah Full Time Equivalent}

Adapun langkah-langkah dalam mencar Full Time Equivalents sebagai berikut:

1. Mencari Faktor Penyesuaian dan Kelonggaran

2. Penentuan Waktu Kerja

Efektif Hari Kerja Efektif =

$(\mathrm{A}-(\mathrm{B}+\mathrm{C}+\mathrm{D})$ Keterangan:

A : Jumlah hari menurut kalender

B : Jumlah hari sabtu dan minggu dalam setahun

C : Jumlah hari libur dalam setahun

D : Jumlah cuti tahunan

3. Perhitungan Beban Kerja FTE

$$
\text { FTE }=\frac{\text { Total Waktu }}{\text { Woktu Kerja Efektif }}
$$

4. Perhitungan Kebutuhan Tenaga Kerja

\section{WorkLoad Analysis}

Suatu proses penentuan jumlah jam kerja orang yang dipergunakan ataupun dibutuhkan dalam menyelesaikan suatubeban kerja tertentu dan dala mwaktu tertentu. Jumlah jam kerja tiap karyawan, akan menghasilkan jumlah karyawan yang dibutuhkan [1]..

\section{Langkah-langkah WorkLoad Analysis}

Adapun langkah-langkah pada metode ini dapat dilihat sebagai berikut:

1. Penentuan Waktu Baku

a. Waktu siklus

b. Waktu Normal

c. Waktu Baku

2. Penentuan Jumlah Tenaga Kerja

Metode WorkLoad Analysis digunakan untuk menentukan kebutuhan jumlah tenaga kerja berdasarkan beban kerja pada waktu tertentu yang dengan waktu kerja dalam satu bulan.

$$
W L A=\frac{\text { Frekuensi } \times \text { Waktu Proses }}{\text { Hori Kerja } \times \text { Jam Kerja }} \times 1 \text { Org }
$$

\section{METODE PENELITIAN}

Adapun teknik pengumpulan data pada penelitian ini dapat dilihat sebagai berikut:

1. Wawancara langsung kepada pemilik dan pekerja.

2. Observasi dilakukan dengan melihat keadaan perusahaan serta memperhatikan karyawan dalam melakukan pekerjaan.

3. Pengumpulan waktu dilakukan dengan mengukur waktu siklus setiap elemen kegiatan.

Hari Kerja pada Toko Daffa adalah 8 hari kerja antara lain hari senin sampai minggu dan bekerja selama 8 jam perhari. Adapun waktu kerja pada Toko Daffa dapat dilihat sebagai berikut:

1. Senin s/d Jum'at dan Minggu

a. $08.30 \mathrm{~s} / \mathrm{d} 12.30$ (Bekerja)

b. $12.30 \mathrm{~s} / \mathrm{d} 13.30$ (Istirahat)

c. $12.30 \mathrm{~s} / \mathrm{d} 16.30$ (Bekerja)

2. Sabtu
a. $08.30 \mathrm{~s} / \mathrm{d} 12.00$ (Bekerja)
b. $12.00 \mathrm{~s} / \mathrm{d} 13.00$ (Istirahat)
c. $13.00 \mathrm{~s} / \mathrm{d} 14.00$ (Bekerja)

\section{HASIL DAN PEMBAHASAN}

\section{A. Hasil Penelitian Jumlah Tenaga Kerja}

Toko Daffa mempe kerjakan karyawan berjumlah 10 orang, adapun pembagiannya dapat dilihat pada Tabel 1 . sebagai berikut:

Tabel 1. Jumlah Tenaga Kerja

\begin{tabular}{l|l} 
Bagian & Jumlah \\
\hline Pencetak Struk Orderan & $\mathbf{1}$ \\
\hline Pengambi IPesanan Orderan & $\mathbf{3}$ \\
\hline Kasir & $\mathbf{1}$ \\
\hline Administrasi Toko & $\mathbf{1}$ \\
\hline Administrasi Gudang & $\mathbf{1}$ \\
\hline Supir` & $\mathbf{3}$ \\
\hline Sumber : Pengumpulan Data
\end{tabular}




\section{Hari Kerja dan Jam Kerja}

Untuk menghitung beban kerja maka diperlukan data hari kerja efektif dalam satu tahun. Adapun hari kerja efektif yang dipakai pada Toko Daffa dapat dilihat pada Tabel 2 sebagai berikut:

Tabel 2. Jumlah Tenaga Kerja

\begin{tabular}{l|l|r|r}
\hline Kode & Faktor & Jumlah & Satuan \\
\hline A & Jumlah Hari Pertahun & 365 & Hari \\
\hline B & Jumlah Hari Libur & 14 & Hari \\
\hline C & Jumlah Cuti Rata-rata & 8 & Hari \\
\hline $\begin{array}{l}\text { Waktu Kerja Efektif (A- } \\
\text { (B+C+D)) }\end{array}$ & 343 & Hari \\
\hline \begin{tabular}{l} 
Waktu Kerja Efektif \\
\hline
\end{tabular}
\end{tabular}

Sumber : Pengumpulan Data

\section{Elemen Pekerjaan}

Perlu mengetahui elemen pekerjaan guna untuk menghitung waktu siklus, Adapun elemen pekerjaan pencetak struk belanjaan dapat dilihat pada Tabel 3 sebagai berikut:

Tabel 3. Elemen Pekerjaan Struk

\begin{tabular}{l|l} 
No & Elemen Pekerjaan \\
\hline $\mathbf{1}$ & Mengetik Orderan Pelanggan \\
\hline $\mathbf{2}$ & Print Struk Orderan Pelanggan \\
\hline \multicolumn{2}{l}{ Sumber : Pengumpulan Data }
\end{tabular}

Adapun elemen pekerjaan pada pekerja yang dipekerjakan untuk mengambil barang orderan yang diberikan oleh operator pencetak struk dapat dilihat pada Tabel 4. sebagai berikut:

Tabel 4. Elemen Pekerjaan Pengambil Barang

\begin{tabular}{|l|l} 
No & \multicolumn{1}{c}{ Kegiatan } \\
\hline $\mathbf{1}$ & Mengambil Barang Orderan Pelanggan \\
\hline $\mathbf{2}$ & $\begin{array}{l}\text { Mengecek Kelengkapan Orderan } \\
\text { Pelanggan }\end{array}$ \\
\hline $\mathbf{3}$ & Mengepak Barang Orderan Pelanggan \\
\hline Sumber : Pengumpulan Data
\end{tabular}

Bagian kasir yang dikerjakan oleh satu operator, Adapun elemen pekerjaan yang dikerjakan oleh kasir dapat dilihat pada Tabel 5. Sebagai berikut:

Tabel 5. Elemen Pekerjaan Kasir

\begin{tabular}{l|l} 
No & \multicolumn{1}{c}{ Kegiatan } \\
\hline 1 & Menghitung Ulang Total Orderan \\
\hline 2 & Melakukan Transaksi \\
\hline \multicolumn{2}{c}{ Sumber : Pengumpulan Data }
\end{tabular}

\section{B. Pembahasan}

Rating Faktor

Adapun rating faktor pada setiap elemen pekerjaan yang diambil berdasarkan pengamatan menggunakan metode Westing house dapat dilihat pada Tabel 6 sebagai berikut:

Tabel 6. Performance Rating

\begin{tabular}{c|c|c|c|c|c}
\hline Opr & Skill & Effort & Condition & Consistency & RF \\
\hline I & 0.03 & -0.04 & 0.04 & 0.01 & $\mathbf{0 . 0 4}$ \\
\hline & 0.06 & 0.00 & 0.06 & 0.04 & $\mathbf{0 . 1 6}$ \\
\hline II & 0.00 & -0.04 & 0.04 & 0.01 & $\mathbf{0 . 0 1}$ \\
\hline & 0.06 & 0.00 & 0.04 & 0.04 & $\mathbf{0 . 1 4}$ \\
\hline & 0.03 & 0.12 & 0.02 & 0.01 & $\mathbf{0 . 1 8}$ \\
\hline III & 0.11 & 0.02 & 0.02 & 0.00 & $\mathbf{0 . 1 5}$ \\
\hline & 0.06 & 0.08 & 0.02 & 0.00 & $\mathbf{0 . 1 6}$ \\
\hline & 0.00 & 0.08 & 0.02 & 0.06 & $\mathbf{0 . 1 6}$ \\
\hline IV & 0.00 & 0.00 & 0.02 & 0.00 & $\mathbf{0 . 0 2}$ \\
\hline & 0.03 & 0.00 & 0.02 & 0.00 & $\mathbf{0 . 0 5}$ \\
\hline & 0.03 & 0.02 & 0.02 & 0.00 & $\mathbf{0 . 0 7}$ \\
\hline V & 0.06 & 0.00 & 0.06 & 0.03 & $\mathbf{0 . 1 5}$ \\
\hline & 0.06 & 0.00 & 0.06 & 0.03 & $\mathbf{0 . 1 5}$ \\
\hline
\end{tabular}

Sumber : Pengumpulan Data

\section{Allowance}

Adapun rekapitulasi dari nilai Allowance pada setiap elemen kerja dapat dilihat pada Tabel 7 sebagai berikut:

Tabel 7. Rekapitulasi Allowance

\begin{tabular}{c|l|c|}
\hline Opr & \multicolumn{1}{|c|}{ Divisi } & Allowance (\%) \\
\hline I & Pencetak Struk & $\mathbf{1 4}$ \\
\hline \multirow{2}{*}{ II } & Pengambil & 14 \\
& Barang & 21 \\
\hline & Orderan & 15 \\
\hline & & 14 \\
\hline
\end{tabular}

\begin{tabular}{c|l|c|}
\hline III & $\begin{array}{l}\text { Pengambil } \\
\text { Barang }\end{array}$ & $\mathbf{2 2 . 5}$ \\
\hline & Orderan & 14 \\
\hline \multirow{2}{*}{ IV } & $\begin{array}{l}\text { Pengambil } \\
\text { Barang }\end{array}$ & 17 \\
\hline \multirow{2}{*}{ V } & Orderan & $\mathbf{2 3 . 5}$ \\
\hline & & 15 \\
\hline & & 17.5 \\
\hline
\end{tabular}

Sumber : Pengumpulan Data

PENGUKURAN BEBAN KERJA DENGAN METODE FULL TIME EQUIVALENT DAN PENENTUAN JUMLAH TENAGA KERJA EFEKTIF MENGGUNAKAN WORKLOAD ANALYSIS 


\section{Waktu Normal dan Waktu Baku}

Setelah dilakukannya penilaian rating faktor, lalu dilakukan perhitungan waktu normal yang dapat dihitung sebagai berikut:

Tabel 8 Waktu Normal dan Waktu Baku

\begin{tabular}{|c|c|c|c|}
\hline Opr & WS & WN & WB \\
\hline I & 162.5 & 227.5 & 259.35 \\
\hline & 42.8 & 49.64 & 56.59 \\
\hline II & 414.6 & 418.74 & 506.68 \\
\hline & 226.2 & 257.86 & 296.54 \\
\hline & 218 & 257.24 & 293.25 \\
\hline III & 371.4 & 427.11 & 486.90 \\
\hline & 220.7 & 256.01 & 313.61 \\
\hline & 224.3 & 260.18 & 296.61 \\
\hline IV & 382.1 & 389.74 & 455.99 \\
\hline & 221.5 & 232.57 & 287.23 \\
\hline & 219.6 & 234.97 & 270.21 \\
\hline V & 15.8 & 18.328 & 20.34 \\
\hline & 52.1 & 60.436 & 70.10 \\
\hline \hline
\end{tabular}

Sumber : Pengumpulan Data

\section{Analisis Beban Kerja dengan Metode FTE}

Pada metode full time equivalent dilakukan perhitungan beban kerja yang diambil berdasarkan waktu baku dan waktu kerja, di mana dapat dilihat sebagai berikut:

Tabel 9. Beban Kerja FTE

\begin{tabular}{c|c|c|}
\hline Opr & FTE & Kategori \\
\hline I & 0.68 & Underload \\
\hline II & 2.28 & Overload \\
\hline III & 2.34 & Overload \\
\hline IV & 2.13 & Overload \\
\hline V & 0.19 & Underload \\
\hline
\end{tabular}

Sumber : Pengumpulan Data

Adapun usulan beban kerja berdasarkan indeks FTE dapat dilihat pada Tabel 10. Sebagai berikut :

Tabel 10. Usulan Perbaikan FTE

\begin{tabular}{c|c|c|}
$\begin{array}{c}\text { Jumlah } \\
\text { Operator }\end{array}$ & \multicolumn{1}{|c}{ FTE } & Kategori \\
\hline $\mathbf{1}$ & 0.87 & Underload \\
\hline $\mathbf{6}$ & 1.12 & Normal \\
\hline
\end{tabular}

Sumber : Pengumpulan Data

\section{Grafik Keseimbangan Beban Kerja Awal dan Usulan}

Adapun grafik kondisi awal beban kerja dapat dilihat pada Gambar 1, Adapun grafik keseimbangan beban kerja dapat dilihat pada Gambar 2. sebagai berikut:

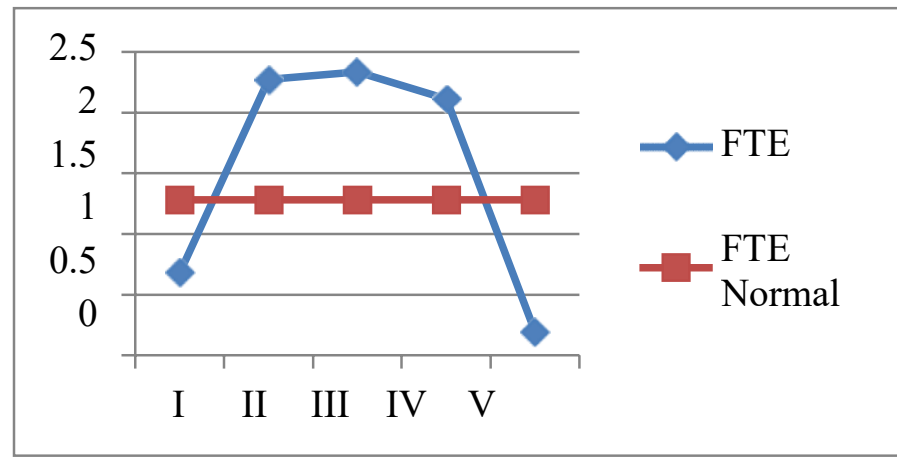

Gambar 1. Grafik Kondisi Awal Beban Kerja Sumber : Pengolahan Data

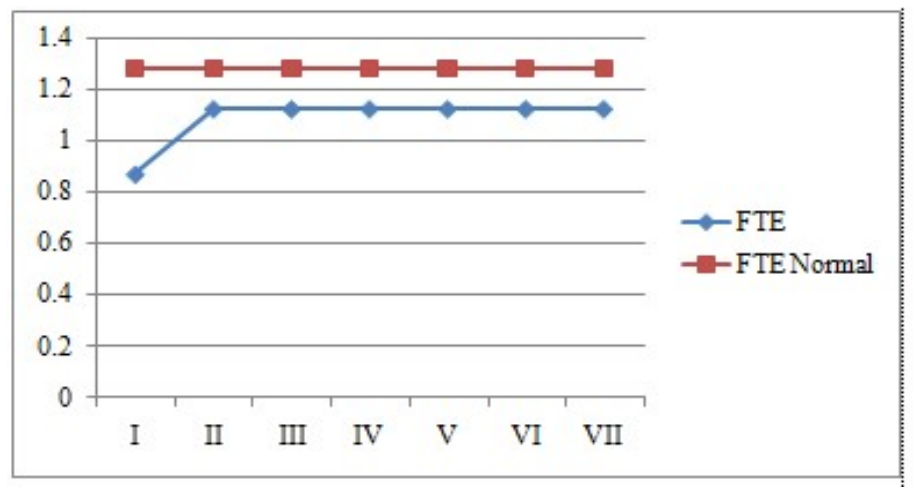

Gambar 2. Grafik Keseimbangan Beban kerja Usulan Sumber : Pengolahan Data 


\section{Analisis Tenaga Kerja Optimal dengan Metode WorkLoad Analysis}

Metode WorkLoad Analysis digunakan untuk menentukan kebutuhan jumlah tenaga kerja berdasarkan beban kerja pada waktu tertentu. Adapun durasi yang dipakai pada metode ini yaitu waktu dalam satu bulan antara lain sebagai berikut:

Di mana dapat dilihat pada elemen pengetik struk didapatkan 0.76 setara dengan 1 orang, hasil perhitungan selengkapnya dapat dilihat pada Tabel 11. Sebagai berikut:

Tabel 11. Rekapitulasi WLA

\begin{tabular}{|c|c|c|c|}
\hline $\begin{array}{c}\text { Tenaga } \\
\text { Kerja } \\
\text { Awal }\end{array}$ & WLA & $\begin{array}{l}\text { Total } \\
\text { WLA }\end{array}$ & $\begin{array}{c}\text { Jumlah } \\
\text { Tenaga } \\
\text { kerja } \\
\text { WLA }\end{array}$ \\
\hline \multirow{3}{*}{1} & 0.63 & \multirow{3}{*}{0.76} & \multirow{3}{*}{ Whr } \\
\hline & 0.13 & & \\
\hline & 2,41 & & \\
\hline \multirow{2}{*}{3} & 1.71 & \multirow{2}{*}{5.78} & \multirow{2}{*}{6} \\
\hline & 1.65 & & \\
\hline \multirow{2}{*}{1} & 0.04 & \multirow{2}{*}{0.21} & \multirow{2}{*}{1} \\
\hline & 0.17 & & \\
\hline
\end{tabular}

Sumber : Pengumpulan Data

Berdasarkan Tabel 11 hasil perhitungan jumlah tenaga kerja optimal dengan menggunakan metode Work Load Analysis dapat dilihat jika pada divisi pencetak struk jumlah tenaga optimal sebesar 1 operator, divisi pengambil orderan didapatkan 6 operator,dan divisi kasir didapatkan tenaga kerja optimal sebesar 1 operator.

\section{Analisis Perbandingan Metode Full Time Equivalent dan Workload Analysis}

Adapun hasil yang didapatkan dengan metode Full Time Equivalent antara lain didapatkan beban kerja pada divisi pencetak struk dengan kategori underload divisi pengambil orderan didapatkan kategori overload dan divisi kasir didapatkan beban kerja underload.

Lalu dilakukan perbaikan dengan tujuan menyeimbangkan beban kerja dan didapatkan hasil penggabungan elemen pekerjaan pada divisi pencetak struk dengan divisi kasir didapatkan beban kerja underload tetapi mengalami peningkatan beban kerja dibandingkan beban kerja sebelumnya dan dilakukan penambahan jumlah tenaga kerja pada divisi pengambil orderan dengan menghasilkan beban kerja yang normal. Hasil analisis menggunakan metode WorkLoad Analysis didapatkan jumlah tenaga kerja optimal antara lain adanya penambahan jumlah tenaga kerja pada divisi pengambil struk dan tidak ada perubahan pada divisi pencetak struk serta divisi kasir.

\section{KESIMPULAN DAN SARAN}

\section{Kesimpulan}

Berdasarkan pengolahan data yang telah dilakukan maka dapat disimpulkan sebagaiberikut:
1. Setelah dilakukan penentuan beban kerja berdasarkan waktu kerja dalam satu tahun maka didapatkan pada operator 1 pencetak struk didapatkan indek FTE sebesar 0.68 yang termaksud underload yaitu beban kerjanya kurang, pada operator 2 pengambil orderan didapatkan indek FTE sebesar 2.28 yang termaksud overload yaitu beban kerja yang berlebihan, pada operator 3 pengambil orderan didapatkan indek FTE sebesar 2.34 yang termaksud kategori overload, pada operator 4 pengambil orderan didapatkan indek FTE sebesar 2.13 yang termaksud kategori overload dan pada kasir didapatkan indek FTE sebesar 0.19 yang termaksud underload yaitu beban kerjanya kurang.

2. Berdasarkan pengolahan data dengan menggunakan metode FTE didapatkan jumlah tenaga optimal pada pencetak struk sebesar 1 orang dan pengambil orderan sebesar 6 orang maka. Sedangkan berdasarkan Workload Analysis pada divisi pencetak struk didapatkan jumlah tenaga kerja optimal sebesar 1 operator ,pada divisi pengambil barang didapatkan jumlah tenaga kerja optimal sebesar 6 operator dan pada divisi kasir didapatkan jumlah tenaga kerja optimal sebesar 1 operator.

\section{Saran}

Adapun saran peneliti yang diberikan untuk penelitian-penelitian berikutnya yaitu terjalinnya kerjasama yang baik antara peneliti dan perusahaan,dan di harapkan perusahaan dapat menerapkan metode usulan perbaikan yang disarankan peneliti untuk memperbaiki kinerja karyawan.

\section{DAFTAR PUSTAKA}

[1] Amri.,Irwansyah,D.,\& Yulisa (2018). Analisis Kebutuhan Jumlah Tenaga Kerja Berdasarkan Metode WorkLoad Analysis Dan Work Force Analysis.7(1),50-56.

[2] Badriyah, Mila. (2015). Manajemen Sumber Daya Manusia. Bandung :CV. Pustaka Setia.

[3] Budaya,P.,W. \& Muhsin, A. 2018. Workload analysis inquality controlde partment.11 (2),134-140.

[4] Fetrina, E. (2018). Analisis Kebutuhan Pegawai Berdasarkan Perhitungan Beban Kerja Pegawai (Studi Kasus:Fakultas Sains Dan Teknologi Uin Syarif Hidayatullah Jakarta). Studia Informatika :JurnalSis temInformasi,10(2),71-76.

[5] Iridiastadi, H.,Yassieri. (2014). Ergonomi Suatu pengantar. Bandung :PT.Remaja Rosdaya karya.

[6] Madiun,W.S. (2017). Analisis Beban Kerja Karyawan Bagian Produksi Dengan Menggunakan Metode Full Time Equivalent (FTE) Di Ud Roti Alvine. Jurnal ARIKA, 11(2), 89-96.

[7] Ningsih,N., \& Prayogo,R. (2019). Science And Technology Analisis Kebutuhan Karyawan Dengan Menggunakan Metode Full Time Equivalent (FTE)Pada Departemen ProduksiPt. Borsya Cipta Communica.3 (2), 98-106.

[8] Roidelindho,K. (2017). Penentuan Beban Kerja Dan JumlahTenaga Kerja Optima 1Pada Produksi Tahu. ISSN 2477-2089, 3(1), 73-81.

[9] Sari,WaOde,Sakka,P. (2017). Analisis Beban Kerja Dengan Metode Full Time Equivalent (FTE) Pada Dokter Umum Di Rumah Sakit Umum Bahteramas Provinsi Sulawesi Tenggara. Jimkesmas,2(6),19.

[10]Tarwaka, Sholichul, Lilik Sudiajeng. (2004). Ergonomi untuk keselamatan, kesehatan kerja dan produktivitas. Surakarta: UNIBAPRESS.

[11] Yanto \& Ngaliman, B. (2017). Ergonomi dasar-dasar studi waktu dan gerakan untuk analisis dan perbaikan system Kerja.Yogyakarta: CV. Andi Offset. 